\title{
VOORTGESETTE DISKUSSIE RONDOM KERKSKEURING
}

Op versoek van die redakteur bied ek hiermee 'n verkorte weergawe van 'n s.i. te uitgebreide antwoord van my van einde 1971.

Sover ek kan oordeel, is daar veral ses kritiekpunte na vore gebring:

\section{Bedenkinge teen art. 29 N.G.B.}

Kritiek is uitgespreek as sou ek kritiek uitgespreek het teen art. 29 N.G.B. [45, 46, 47, 49] (Die vierkant-hakies verwys na In die Skriflig, Junie 1971). Laat ek ons broeders gerusstel: ek het nie die minste probleme met art. 29 N.G.B. nie - asook met die ondertekeningsformulier. Wél ondervind ek moeite met die simplistiese en a-historiese interpretasie van art. 29 N.G.B. Want behalwe die reg tot ,afskeiding" vanuit die nie-kerk, word daar in artt. 28 en 29 tot 3/4 maal toe vermeld dat ons ons nié mag "onttrek" of ,afskei" van die ware kerk nie.

Die groot leemte in die kritiek op my bestaan daarin dat niémand ' $n$ poging aangewend het om indringend en eksegeties in te gaan op die vele Skrifgegewens wat ek na vore gebring het nie. Gereformeerde teologie hou hom tog met die Bỷbel as Gods Woord besig! 'n Interessante en boeiende - maar nie belofteryke en hoopvolle ekklesiologiese skaakspel ontstaan wanneer ons mekaar skaakmat probeer sit, die een met 'n skuif vanuit die kerkgeskiedenis [52], die ander met een uit die Bybel. Dra die skuif (slegs) vanuit die kerkgeskiedenis nie (onbedoeld) 'n Roomse tendens en relativeer dit nie die sola Scriptura nie?

Hierdie basiese leemte in die kritiek blyk nêrens duideliker as daaruit dat daar slégs van ,bedenkinge" teen die Belydenis sprake is en nie ook teen die Skrif nie. Wie die Belydenisskrifte aantas, moet noodwendig die Skrif aantas, omdat die Belydenisskrifte op die Skrif rus en daaruit voortkom. Kritiek van anti-konfessionalisme moet dus deurstoot tot die kern: anti-Skriftuurlikheid. In die handhawing van en binding aan die Belydenis gaan dit "in wese nie om die Belydenis as sodanig nie, maar om die handhawing van en binding aan die Skrif" (S. C. W. Duvenage: In die Skriflig, Sept. 1971, 31).

\section{Bedenkinge teen Sinodale besluite}

Inderdaad het ek kritiek uitgespreek op Sinodale besluite [45, 49]. Saam met baie ander kerkregkundiges is ek van mening dat dit op verantwoordelike wyse wel gedoen mag word, soos bv. op talle plekke gebeur in Handleiding by die Kerkorde van die Geref. Kerk in S.A. (1966). My kritici het tewens ook al dieselfde gedoen: ons sinodale besluit van 1967 in verband met ons verhouding tot die Geref. Kerke in Nederland is bestempel as ,'n stukkie volstruispolitiek" (In die Skriflig, Aug.-Sept. 1969, 11) (selfs in 1970 het ons Sinode nog besluit dat broederlike bande „nooit oorhaastig" verbreek mag word nie, Acta 1970, 80); my bewering dat kerk = gelowiges 
is bestempel as simplisties [50], direk in stryd met ons sinodale siening van kerk $=$ gelowiges $($ Acta 1970, 64).

Daarby moet ons daarteen waak om nie aan sinodale besluite dieselfde gesag toe te ken as aan die Belydenisskrifte nie.

In verband met my opstel wat op 8 Junie 1970 voorgedra is terwyl die Sinode reeds in Februarie 1970 besluit het dat 'n gesprek op plaaslike vlak nie mág nie [45]: my kritikus weet dat ek nie die Sinodale vergadering bygewoon het nie en eers van die betrokke besluit kennis kon geneem het teen die éinde van 1970 nadat die Acta verskyn het.

\section{Bedenkinge teen die bestaansreg van die Geref. Kerk}

Kritiek is uitgespreek dat my kerkbegrip - ironies genoeg swewend is [51] en dat ek selfs ' $n$,streep trek" deur die bestaansreg van die Geref. Kerk in S.A. („my eie”), dit "twyfelagtig bejeën" $[45,49]$.

Dit is ironies, omdat ek my persoonlik baie beywer vir meer presiesheid in die hantering van die woordjie „kerk". Ek het in my opstel ook niks anders probeer doen nie as om die Nieu-Testamentiese kerkbegrip, soos W. J. Snyman dit so onoortroffe aan ons geleer het, konsekwent toe te pas op die problematiek van kerkskeuring. Helaas is verwarring geskep a.g.v. drukkersfoute, omdat soms 'n kleinletter , $k$ " geset is waar ek 'n hoofletter „,K" geskryf het (bedoelende die Universele KERK, in onderskeiding van die plaaslike kerk).

Indien dit my bedoeling sou gewees het om 'n streep te trek deur die bestaan van die Geref. Kerk in S.A., dan kom hierdie redenasie - wanneer dit in sy logiese konsekwensie tot in die absurde deurgetrek word - daarop neer dat ook die bestaansreg van die Geref. Kerke in Nederland en Christelijke Geref Kerk (en álle „afgeskeie" kerkverbande) disputabel is, ja, dit sou dan neerkom op 'n terugroep na die Rooms-Katolieke Kerk! 'n Kerk rus nie op sy historisiteit nie, maar op die belydenis dat Jesus die Messias, die Seun van God is (Matt. $16: 16$ ).

En dan, wie van „my eie” kerk praat, versubjektiveer die kerk. Die Nuwe Testament spreek nooit van die kerk as ,kerk van my" nie, maar altyd as ,kerk van God”, of - slegs 'n enkele keer — as „kerk van Christus" (Rom. $16: 16$; Gal. 1 : 22). Wat eksklusief aan die Here behoort, kan nie terselfdertyd ook mýne wees nie.

Die probleem rondom ,kerk en kerkverband" is moeilik [52]. Gewoonlik word beweer dat „die kerke eers één in Belydenis moet wees voordat daar sprake van 'n kerkverband kan wees" (Handleiding by die Kerkorde, 20). Die vraag wat egter hier ontstaan, is die volgende: Kan ons „Belydenis" en „,belydenisskrifte” identifiseer? Indien wel, stuit ons voor die besonder eienaardige situasie dat ons enersyds met 'n kerkgroep, die Free Church of Scotland, in enger korrespondensie staan terwyl hulle 'n ánder belydenisskrif as ons het, nl. die Westminsterse Konfessie (maar beteken dit dat hulle 'n ánder belýdenis het?); terwyl, andersyds, ons nié met kerkgroepe in korrespondensie staan wat presies dieselfde belydenisskrifte as ons het, soos bv. die N.G.K. en N.H.K. Die konkrete kerklike situasie 
getuig dat belydenis en belydenisskrifte nie identies is nie - miskien wat die kernwaarhede betref, maar wat is dit, en wie maak dit uit? - sodat kerkgroepe met nie-identiese belydenisskrifte kan korrespondeer, en kerkgroepe met identiese belydenisskrifte apart kan bly bestaan. Vandaar my vraag na die betekenis van die doop i.v.m. die probleem van kerkverband en kerklike eenheid.

\section{Beïnvloeding van nuwe teologie}

In my artikel sou allerlei invloed van die „nuwe teologie” merkbaar wees $[45,46]$. Daar is vandag egter soveel „nuwe teologieë" in die lug dat ons hier konkreet en spesifiek moet wees. Ons dink aan die "dialektiese teologie" (Karl Barth), die „kerugmatiese teologie” (R. Bultmann), die „God-is-dood-teologie” (W. Hamilton en J. J. Altizer), die ,teologie van die geskiedenis” (W. Pannenberg), die „teologie van die hoop" (J. Moltmann), die ,teologie van die samelewing" (H. D. Wendland), die "teologie van die rewolusie" (R. Shaull), die „swart teologie" (J. H. Cone). Watter "nuwe teologie" bedoel my kritici? En presies waar in my opstel is die invloed hiervan merkbaar?

\section{Beïnvloeding van ekumeniese ideaal}

Invloed van die ekumeniese ideaal sou in my opstel merkbaar wees [45, 46]. Bestaan daar egter nie so iets as 'n Bybels-verantwoorde ekumeniese ideaal (ten gunste waarvan ons Sinode hom in geen onduidelike taal uitgespreek het, Acta 1967, 415), en 'n onbybelse ekumeniese ideaal nie? Vir eersgenoemde sê ek graag „,ja”, soos ook talle teoloë uit ons eie midde (ek het in voetnoot 80 verwys na T. van der Walt, L. F. Schulze, W. J. Snyman, en ek kon die name van B. Duvenage en B. J. de Klerk nog bygevoeg het).

\section{Beïnvloeding van 'n diesseitigkeits-koninkryksbegrip}

Die eenheid van die KERK is in die lig van Matt. $12: 25$ van vitale belang vir die koninkryk van God en sy koms. Van my kritici meen dat my koninkryksbegrip „vals” is, nl., „diesseitig” [46-47]. Hierop wil ek nie mér sê nie as dat dit m.i. 'n volkome onvrugbare en valse dilemma is om die diesseitigkeits- en jenseitigkeitskarakter van die koninkryk van God teen mekaar uit te speel. Béide is dimensies van een en dieselfde Ryk. Ek meen dat die jongste studies van Ridderbos, Berkouwer, Berkhof, Van der Walt en König oor hierdie tema dit baie duidelik aangetoon het.

1 April 1972.

J. H. van Wyk. 